\title{
Larvicidal effect of dried leaf extracts from Pinus caribaea against Aedes aegypti (Linnaeus, 1762) (Diptera: Culicidae)
}

\author{
Efeito larvicida dos extratos de folhas secas de Pinus caribaea contra \\ Aedes aegypti (Linnaeus, 1762) (Diptera: Culicidae)
}

\author{
Luiz Alberto Kanis ${ }^{1}$, Rodrigo Damian Antonio ${ }^{1}$, Ériston Paes Antunes ${ }^{1}$, \\ Josiane Somariva Prophiro ${ }^{2}$ and Onilda Santos da Silva ${ }^{3}$
}

\begin{abstract}
In this study, the larvicidal activity of dried leaf extracts from Pinus caribaea Morelet against Aedes aegypti was evaluated for the first time. Pinus caribaea extracts were obtained by macerating dried leaves in alkaline hydroethanol, ethanol and acetone solutions followed by evaporation under reduced pressure. The lignin content was quantified using the thioglycolic acid complexation method. Lethality bioassays $\left(\mathrm{LC}_{50}\right.$ and $\left.\mathrm{LC}_{90}\right)$ were carried out in accordance with the recommendations of the World Health Organization. The results showed that the acetone extract from Pinus caribaea was more active, and that larvicidal activity was associated with lignin concentration.
\end{abstract}

Key-words: Aedes aegypti. Pinus caribaea. Larvicide. Extract.

\section{RESUMO}

Neste trabalho foi avaliada pela primeira vez a atividade larvicida contra Aedes aegypti de extratos obtido a partir de folhas secas de Pinus caribae. Os extratos de Pinus caribaea foram obtidos a partir da maceração de folhas secas em solução hidroetanólica alcalina, etanol e acetona, seguido de evaporação sob pressão reduzida. 0 teor de lignina foi quantificado usando o método de complexação com ácido tioglicóliclo. Os ensaios de letalidade foram conduzidos de acordo com a recomendação da Organização Mundial da Saúde. Os resultados demonstraram que o extrato obtido com acetona foi mais ativo, e a atividade larvicida esta associada com a concentração de ligninas.

Palavras-chaves: Aedes aegypti. Pinus caribaea. Larvicida. Extratos.

Aedes aegypti is the primary vector of the dengue viruses, a group of four serotypes of single-stranded RNA virus ${ }^{3}$. The spread of the dengue virus via its Aedes mosquito vector throughout most of the tropics has led to worldwide resurgence of the epidemic dengue, including dengue hemorrhagic fever5.

Insecticides are one of the major tools for controlling vector populations and for reducing the transmission of human pathogens ${ }^{18}$. However, continuous use of one insecticide may cause changes to susceptibility status for many mosquito species. Over recent years, resistance has been reported worldwide in several Aedes aegypti populations ${ }^{811} 141624$.

One alternative for avoiding resistance among mosquitoes could be the use of products involving insecticidal substances from plants. Such substances have several advantages compared with the use of synthetic insecticides. Natural insecticides are obtained from renewable resources and are quickly degradable in the environment ${ }^{22}$. Thus, several studies worldwide have

\footnotetext{
1. Research group in pharmaceutical technology, University of southern Santa Catarina, Tubarão, SC, Brazil. 2. Research Group in Immuneparasitology, University of Southern Santa Catarina, Tubarão, SC, Brazil. 3. Department of Microbiology, Sector of Parasitology, Federal University of Rio Grande do Sul, Porto Alegre, RS, Brazil Financial support: UNISUL/FAPESC

Address to: Dr. Luiz Alberto Kanis. Av. José Acácio Moreira 787, 88704-900 Tubarão, SC, Brazil.

Tel: 5548 3621-3283, Fax: 5548 3621-3108.

e-mail: luiz.kanis@unisul.br

Received in 06/04/2009

Accepted in 20/07/2009
}

reported on the use of plant extracts as potential larvicides for many mosquito species ${ }^{12025}$. One of the most promising groups of plants that have been studied is the Meliaceae family, for example the species Azadirachta indica ${ }^{171926}$. These plants are known to possess substances such as limonoids that are effective against many mosquito species.

Lignins are another important type of plant substance. These are polymers that accumulate in the walls of plant cells, thereby giving such plants great rigidity. They are important for water and nutrient transportation ${ }^{1327}$. Furthermore, it has already been proven that lignin accumulations in wood protect it against fungus and bacteria, and also against attacks by herbivores ${ }^{10}$.

The chemical structure of these macromolecules includes phenylpropanoid units called $\mathrm{C}_{6} \mathrm{C}_{3}$ or simply $\mathrm{C}_{9}$ that occur irregularly in the chain. They originate from condensation of coumaryl, coniferyl and sinapyl alcohols ${ }^{23}$.

Studies have shown that lignin from some plant species induces toxic effects on Aedes aegypti larvae ${ }^{28}$ and antifungal activity on Microsporum canis, and Thrichophyton rubrum ${ }^{15}$.

Pinus species (Pinaceae) are known to contain a variety of important chemical compounds such as lignin. Pinus caribaea Morelet, known as Brazilian pine, has worldwide economic importance since it is extensively used in the wood industry and for obtaining cellulose. Its resin has also been used to manufacture gums, cleaning materials, etc ${ }^{21}$. 
In plantation areas in Brazil, Pinus caribaea leaves are discarded in the environment. Although the possibilities for their use in mosquito control are still unknown, they could form an abundant source material for such applications.

For this reason, the aim of this study was to evaluate the larvicidal effect of Pinus caribaea leaf extracts, based on their lignin content, against Aedes aegypti.

\section{MATERIAL AND METHODS}

Pine leaves were collected in Rio do Pouso, a locality near Tubarão (28.28.00 S, 049.00.25 W), Santa Catarina, Brazil, in August 2006. Botanical identification was conducted by a specialist and an exsiccate was kept in the Laelia purpurata Herbarium of the University of Southern Santa Catarina. The leaves were kept for seven days at $35^{\circ} \mathrm{C}$ for dehydration and were then ground up. The resultant material was kept in covered plastic vials.

Leaf extraction. The extracts were obtained using three kinds of solvent: ethanol, acetone and alkaline hydroethanol solution (20/80; pH raised to 12 using $\mathrm{NaOH}$ ). The ground leaves (300g) were mixed in 1.5 liter of these solvents and kept under constant agitation over a five-day period. The extracts obtained were filtered and the solvent was evaporated at $40^{\circ} \mathrm{C}$ under vacuum. The raw extract was stored in a refrigerator until analysis.

Lignin assay. To investigate the quantities of lignin in the extracts, assays were performed in accordance with the method described in Geiger et $\mathrm{al}^{9}$. An amount of $500 \mathrm{mg}$ of extract was incubated with $0.4 \mathrm{ml}$ of thioglycolic acid and $5 \mathrm{ml}$ of $2 \mathrm{~N} \mathrm{HCl}$ for five hours at $90^{\circ} \mathrm{C}$. The suspension was filtered and the residue was filled with water until $\mathrm{pH} 5.0$ was reached. The resultant material was suspended in $5 \mathrm{ml}$ of $2 \% \mathrm{NaOH}$, for 24 hours, at room temperature. The suspension was than filtered again and washed many times with $5 \mathrm{ml}$ aliquots of water. The thioglycoliclignin complex was obtained by adding $5 \mathrm{~N} \mathrm{HCl}$ until $\mathrm{pH} 1.5$ was reached. The insoluble complex was centrifuged at 4,500g for 20 minutes, washed with water and dried at $80^{\circ} \mathrm{C}$ for $48 \mathrm{~h}$. The material obtained was described in terms of percentage of ligninthioglycolic complex.

Mosquito strains. The Rockefeller strain of Aedes aegypti was originally obtained from the Brazilian National Health Foundation (Fundação Nacional de Saúde), and was continuously maintained in our laboratory. The insects were reared under a photoperiod regime of 14 hours of light to 10 hours of darkness. The larvae were reared using powdered pet food (Purina ${ }^{\circledR}$ Cat Chow ${ }^{\circledR}$ ) $0.2 \mathrm{~g} / 100 \mathrm{ml}$, three times a week. Adult males and females were continuously provided with a 5\% honey solution, while females were blood-fed on BALB/c mice twice a week in order to obtain eggs for colony development.

Larva susceptibility bioassay. The bioassays were performed in accordance with the World Health Organization protocols $^{29}$. The susceptibility of the larvae was assessed by exposing the population to several concentrations of Pinus caribaea. Late third or early fourth-instar larvae were collected using a Pasteur pipette, selected and transferred using a tiny brush to plastic jars containing extracts of Pinus caribaea at concentrations ranging from 31.2 to $700 \mathrm{ppm}$. The tests were conducted in quadruplicate: for each test, 25 larvae were kept in $100 \mathrm{ml}$ of boiled water with the different extract concentrations. Control samples were incubated with the same concentration of ethanol and alkaline hydroethanol solution that was used to obtain the Pinus caribaea extracts. The percentage larva mortality was determined 24 hours after incubation, at a temperature of $25^{\circ} \mathrm{C}$ and relative humidity of $80 \pm 10 \%$, in a climate-controlled chamber (Eletrolab®, model 132FC). Larvae were considered dead if they demonstrated total absence of movement when lightly prodded with a teasing needle. The mortality rate was calculated in relation to the total number of Aedes aegypti larvae killed in each bioassay. The lethal concentrations $\left(\mathrm{LC}_{50}\right.$ and $\left.\mathrm{LC}_{90}\right)$ were interpolated by Probit analysis, as described by Finney ${ }^{7}$.

\section{RESULTS AND DISCUSSION}

Crude extracts obtained from Pinus caribaea leaves showed resin characteristics with $\mathrm{pH}$ around 3.0. According to Saliba ${ }^{23}$, the acid pH of such extracts is attributable to phenolic acid.

Table 1 shows the concentrations required for killing the Aedes aegypti larvae after 24 hours of exposure $\left(\mathrm{LC}_{50}\right.$ and $\mathrm{LC}_{90}$, $\mathrm{ppm}$ ), the correlation with lignin content (determined by means of thioglycolic complexation methods) and the total amount of extract material obtained from Pinus caribaea leaves. The low water solubility of ethanol and alkaline hydroethanol extracts limited the ability to obtain solutions with higher extract concentrations. It was therefore impossible to determine the $\mathrm{LC}_{90}$ (Table 1).

\section{TABLE 1}

Larvicidal activity of Pinus caribaea extracts against the late third or early fourth instar larvae of Aedes aegypti after 24 hours of exposure, and correlation with lignin content and total extractive material.

\begin{tabular}{lcccc}
\hline Extract & $\begin{array}{c}\text { Lignin } \\
(\%)\end{array}$ & $\begin{array}{c}\text { Extractive } \\
\text { material }(\%)\end{array}$ & $\begin{array}{c}\mathrm{LC}_{90} \\
\mathrm{ppm}\end{array}$ & $\begin{array}{c}\mathrm{LC}_{90} \\
\mathrm{ppm}\end{array}$ \\
\hline Acetone & $45.0 \pm 2.6$ & 9.5 & $92(73-112)$ & $760(834-2207)$ \\
Ethanolic & $21.7 \pm 1.2$ & 10.7 & $713(622-826)$ & $* *$ \\
Alkaline hydroethanolic & $14.8 \pm 0.3$ & 16.8 & $2051^{*}(1615-2875)$ & $* *$
\end{tabular}

Level of confidence $95 \%, \mathrm{LC}_{90}$ i lethal concentration that causes $50 \%$ of mortality, $\mathrm{LC}_{9}$ : lethal concentration that causes $90 \%$ of mortality.

*extrapolated from regression linear obtained from Probit, **not determinated.

The results showed that the alkaline hydroethanol solvent had the greatest ability to extract total substances from Pinus caribaea leaves $(16.8 \%)$. This result can probably be attributed to the intermediate polarity and elevated $\mathrm{pH}$ of the solvent, which can increase the solubility of phenolic acid components. However, the lignin content obtained was very low $(14.8 \%)$, regardless of the low lignin solubility in water. Ethanol and acetone demonstrated lower ability to extract the total substances, but good ability to extract lignin. Better results were obtained with acetone, since $45 \%$ of the lignin content was obtained from the total substances extracted. According to Saliba ${ }^{23}$, this is attributable to the higher lignin solubility in acetone. 
Alkaline hydroethanol, ethanol and acetone extracts gave $\mathrm{LC}_{50}$ of 2051 (1615-2875) ppm, 713 (622-826) ppm and 92 (73-112) ppm respectively. The acetone extract was 22 times more potent than the alkaline hydroethanol extract and eight times more potent than the ethanol extract. The $\mathrm{LC}_{50}$ from acetone extracts (92ppm) was similar to that described by Ansari et al, who tested a pine oil from Pinus longifolia against larvae of urban mosquitoes in India such as Anopheles culicifacies, Culex quinquefasciatus and Aedes aegypti ${ }^{2}$. The data on the larvicidal activity showed $\mathrm{LC}_{50}$ of 82.1ppm for Aedes aegypti, 85.7ppm for Culex quinquefasciatus and 112.6ppm for Anopheles stephensi.

In this study, the quantity of lignin was assayed because of its importance as a larvicide. These chemical compounds were also tested against other mosquito species. David et $\mathrm{al}^{4}$ and Tilquin et $\mathrm{a}^{28}$ reported that lignin extracted from leaves demonstrated a toxic effect on Aedes aegypti larvae. The correlation between lignin content and larvicidal activity can be seen better in Figure 1.

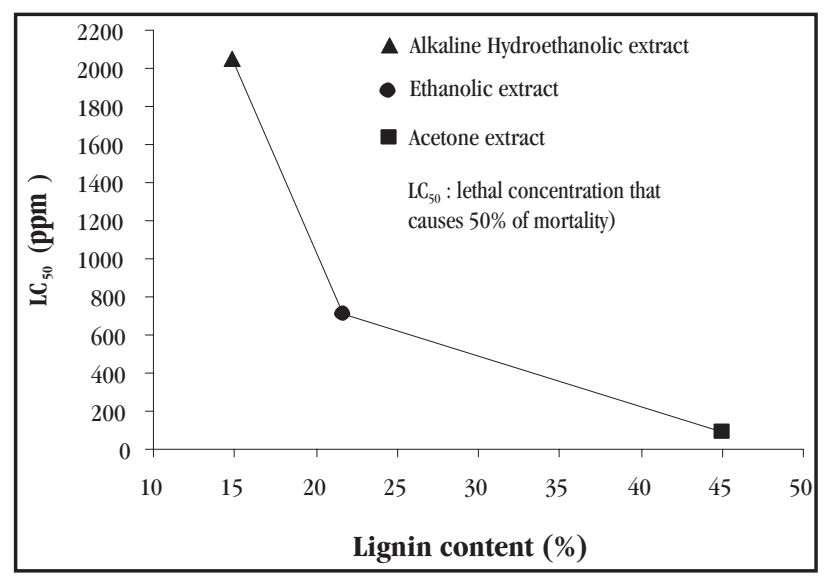

FIGURE 1

Lignin contents correlation with larvicidal activity of Pinus caribaea extracts.

These results showed that greater lignin content in the extract promoted increased larvicidal activity. However, the decrease in $\mathrm{LC}_{50}$ was not linear with the increase in lignin content, and this result suggests that the activity was dependent not only on lignins, but also perhaps on other chemical constituents of Pinus, such as phenolic acid derivatives.

Komalamisra $^{12}$ classified the larvicidal activity of plants as effective when $\mathrm{LC}_{50}$ was lower than $750 \mathrm{ppm}$, moderate when it was $50-100 \mathrm{ppm}$ and high when it was lower than 50ppm. Thus, the activity of the acetone extracts from Pinus caribaea was considered moderate, while the ethanol extract was effective and alkaline hydroethanol extracts showed low activity. Comparing the activity of Pinus caribaea acetone extracts to that of other plants, like Meliaceae, this could be a good source for larvicidal development. Moreover, the Environmental Protection Agency of the United States has classified pine lignins in toxicity category IV, with very low acute toxicity: $\mathrm{LC}_{50}$ of $2-5 \mathrm{~g} / \mathrm{kg}$ for rats and $1-3 \mathrm{~g} / \mathrm{l}$ for fish ${ }^{6}$.

\section{REFERENCES}

1. Amer A, Mehlhorn H. Larvicidal effects of various essential oils against Aedes, Anopheles, and Culex larvae (Diptera, Culicidae). Parasitology Research 99:466$472,2006$.

2. Ansari MA, Mittal PK, Razdan RK, Creehari U. Larvicidal and mosquito repellent activities of Pine (Pinus longifolia, family: Pinaceae) oil. Journal of Vector Borne Diseases 42:95-99, 2005.

3. Bangs MJ, Pudiantari R, Gionar YR. Persistence of Dengue Virus RNA in Dried Aedes aegypti (Diptera: Culicidae) Exposed to Natural Tropical Conditions. Journal of Medical Entomology 44:163-167, 2007.

4. David JP, Rey D, Meyran JC, Marigo G. Larvicidal effect of a cell-wall fraction isolated from alder decaying leaves. Journal of Chemical Ecology 26: 901-913, 2000 .

5. Edelman R. Dengue vaccines approach the finish line. Clinical Infectious Diseases 45:56-60, 2007.

6. Enviromental Protection Agency. Oxidizing pine lignin, sodium salt: Exemption Tolerance 61:13476-13478, 1996.

7. Finney DJ. Probit analysis. Cambridge University Press, Cambridge, United Kingdom, 1971.

8. Flores AE, Grajales JS, Salas IF, Garcia GP, Becerra MH, Lozano S, Brogdon WG, Black WC4th, Beaty B. Mechanisms of insecticide resistance in field populations of Aedes aegypti (L.) from Quintana Roo, Southern Mexico. Journal of American Mosquitoes Control Association 22:672-677, 2006.

9. Geiger JP, Rio B, Nicole M, Nandris D. Biodegradation of Hevea brasiliensis woodby Rigidoporus lignosus and Phellinus noxius. Hamburg; Sonderdruck aus. European Journal of forest pathology 6: 147-159, 1986.

10. Gottlieb OR. Ligninas de plantas amazonicas: investigaçoes biológicas e químicas. Acta Amazonica 18:333-344, 1988.

11. Jirakanjanakit N, Rongnoparut P, Saengtharatip S, Chareonviriyaphap T, Duchon S, Bellec C, Yoksan S. Insecticide susceptible/resistance status in Aedes (Stegomyia) aegypti and Aedes (Stegomyia) albopictus (Diptera: Culicidae) in Thailand during 2003-2005. Journal of Economic Entomology 100:545-550, 2007.

12. Komalamisra N, Trongtokit Y, Rongsriyam Y, Apiwathnasorn C Screening for larvicidal activity in some Thai plants against four mosquito vector species. Southeast Asian Journal of Tropical Medicine and Public Health 6:1412-1422, 2005

13. Lima NMF, Abreu CAM, Maranhão LCA, Sales FG. Kinetic evaluation and modeling of lignin catalytic wet oxidation to selective production of aromatic aldehydes. Industrial \& Engineer Chemistry Research 45:6627-6631, 2006.

14. Liu H, Cupp EW, Guo A, Liu N. Insecticide resistance in Alabama and Florida mosquito strains of Aedes albopictus. Journal of Medical Entomology 41:946$952,2004$.

15. Lopez MR, Gonzalez MA, Acosta TL, Caceres JG. Actividad antifúngica in vitro del Pinus caribaea (pino macho). Revista Cubana de Plantas Medicinales 2:25-29, 1997.

16. Montella IR, Martins AJ, Vianna-Medeiros PF, Braga IA, Valle D. Insecticide Resistance Mechanisms of Brazilian Aedes aegypti Populations from 2001 to 2004. American Journal of Tropical Medicine and Hygiene 77:467-477, 2007.

17. Mulla MS, Su T. Activity and biological effects of neem products against arthropods of medical and veterinary importance. Journal of American Mosquitoes Control Association 15:133-152, 1999.

18. Paul A, Harrington LC, Scott JG. Evaluation of Novel Insecticides for Control of Dengue Vector Aedes aegypti (Diptera: Culicidae). Journal of Medical Entomology 43:55-60, 2006.

19. Prophiro JS, Rossi JCN, Pedroso MF, Kanis LA, Silva OS. Leaf extracts of Melia azedarach Linnaeus (Sapindales: Meliaceae) act as larvicide against Aedes aegypti (Linnaeus, 1762) (Diptera: Culicidae). Revista da Sociedade Brasileira de Medicina Tropical 41:560-564, 2008.

20. Rajkumar S, Jebanesan A. Larvicidal and oviposition activity of Cassia obtusifolia Linn (Family: Leguminosae) leaf extract against malarial vector, Anopheles stephensi Liston (Diptera: Culicidae) Parasitology Research 104:337-340, 2009 . 
21. Rizzini CT. Árvores e Madeiras Úteis do Brasil: Manual de Dendrologia Brasileira. Editora Edgard Blucher Ltda, São Paulo, Brasil, 1986.

22. Roel AR. Utilização de plantas com propriedades inseticidas: uma contribuição para o Desenvolvimento Rural Sustentável. Revista Internacional de Desenvolvimento Local 1: 43-50, 2001.

23. Saliba EOS, Rodriguez NM, Morais SAL, Piló-Veloso D. Lignins - Isolation methods and chemical characterization. Ciência Rural 31:917-928, 2001.

24. Seccacini E, Lucia A, Zerba E, Licastro S, Masuh H. Aedes aegypti resistance to temephos in Argentina. Journal of American Mosquitoes Control Association 24:608-609, 2008.

25. Senthilkumar N, Pushkala Varma, Gurusubramanian G. Larvicidal and adulticidal activities of some medicinal plants against the Malarial Vector, Anopheles stephensi (Liston). Parasitology Research 104:237-244, 2009.
26. Silva OS, Prophiro JS, Rossi JCN, Kanis LA, Blazius RD, Romão PRT. Larvicidal effect of Carapa guianensis (Meliaceae) against Aedes aegypti (Diptera: Culicidae). Journal of American Mosquitoes Control Association 22:699-701, 2006.

27. Simões CMO, Shenkel EP, Gosmann G, Mello JCP, Mentz LA, Petrovick PR. Farmacognosia:da planta ao medicamento. Editora da UFRGS/Editora da Universidade Federal de Santa Catarina, Porto Alegre/Florianópolis, 2003.

28. Tilquim M, Meyran JC, Esther M, Marigo G. Hot Extraction And Characterization of a Ligninlike Fraction Involved in Larvicidal Effects of Decomposed Leaf Litter against Mosquito. Journal of Chemical Ecology 28:1497-1510, 2002.

29. World Health Organization. Instructions for determining the susceptibility or resistance of mosquito larvae to insecticides. WHO/NBC/81,807. World Health Organization, Geneva, 1981. 